\title{
On the Fiscal Burden of Various Income Groups of the Population
}

\author{
E. V. Ordynskaya ${ }^{a, *}$ and M. V. Cherkovets ${ }^{a}$ \\ ${ }^{a}$ Institute of Economic Forecasting, Russian Academy of Sciences, Moscow, Russia \\ *e-mail:eord@mail.ru \\ Received April 5, 2021; revised April 21, 2021; accepted May 19, 2021
}

\begin{abstract}
The distribution of the tax burden between different income groups of the population is closely related to the implementation of the principle of fairness of taxation. In Russia, the largest tax burden falls on the poorest groups of the population. The growing polarization of incomes of the population, aggravated by the pandemic, entails the need to reform the tax system, primarily in the area of taxation of personal income. A fairly large number of studies have been devoted to this problem, but the authors of papers on this topic have not yet succeeded in forming a unified opinion. In connection with the above circumstances, the authors of this article are making an attempt to propose possible directions for transforming the domestic tax system, which would make it possible to more evenly distribute the tax burden between different groups of the population. The results of the research, conclusions and individual proposals can be useful to state bodies in the development of the main directions of reforming the tax policy of the Russian Federation.
\end{abstract}

Keywords: tax system, fairness of taxation, transformation of the tax system, personal income, decile income groups

DOI: $10.1134 / \mathrm{S} 1075700721060113$

Tax revenue situation in 2020. Eliminating the consequences of the COVID-19 pandemic will require a very significant effort and funds, the main source of which is taxes. Attraction of additional tax revenues will increase the tax burden. Certain measures in this direction are outlined in most countries, including the Russian Federation [1]. A number of experts believe that the pandemic could "lead another half a billion people to poverty" [2], while the introduction of additional taxes will only aggravate the situation.

In addition, the economic crisis, the negative consequences of the pandemic, etc. led to a significant decrease in the economic activity of business and, as a result, to a reduction in tax revenues. It can be assumed that, in addition to the obvious reasons for the decrease in tax revenues, this process was influenced by the desire of businesses, especially small and medium-sized ones, to go into hand-to-hand circulation during the pandemic. Most likely, this is largely due to the restrictive "anti-COVID" measures, which led to the fact that a significant number of enterprises were forced to reduce their activities, and many companies completely suspended them. Against this background, there has also been a withdrawal of some activities into the nonobserved sector. For example, these phenomena, first of all, were traced in the beauty industry and in other activities related to the service sector. A consequence of this "optimization of tax payments" was also a reduction in tax revenues.
In general, the reduction in tax revenues of the budget by the end of 2020 looks as follows. As of January 1,2021 , corporate income tax revenues decreased compared to the same period last year by about $12 \%$, and mineral extraction tax revenues by $35 \%$, and state duty revenues have also significantly decreased ${ }^{1}$ (by about 14\%) [3]. This circumstance may also indirectly indicate a decrease in economic activity, since a decrease in incoming payments in the form of a state duty is most likely associated with a decrease in the number of transactions subject to appropriate state registration.

The number of profitable organizations has dropped significantly. As of January 1, 2020, their number was 856418 units, and as of October 1, 2020, only 730315 units. (Fig. 1) [3]. In general, the margin of the total profit earned also decreased.

At the same time, according to the results of 2020, there was an increase in revenues for individual taxes. In particular, it is necessary to note the growth of revenues from the excess profits tax (EPT) from the extraction of hydrocarbons; it amounted to 47\% [3]. Also, a significant increase in receipts (43\%) [3] was noted for domestic excise taxes. Most likely, in the first case, this growth is due to the fact that EPT is a new

\footnotetext{
${ }^{1}$ State duty is a fee levied from individuals and legal entities when they apply to state bodies, local self-government bodies, and other bodies for the performance of legally significant actions in relation to these entities, provided for by the Tax Code of the Russian Federation.
} 


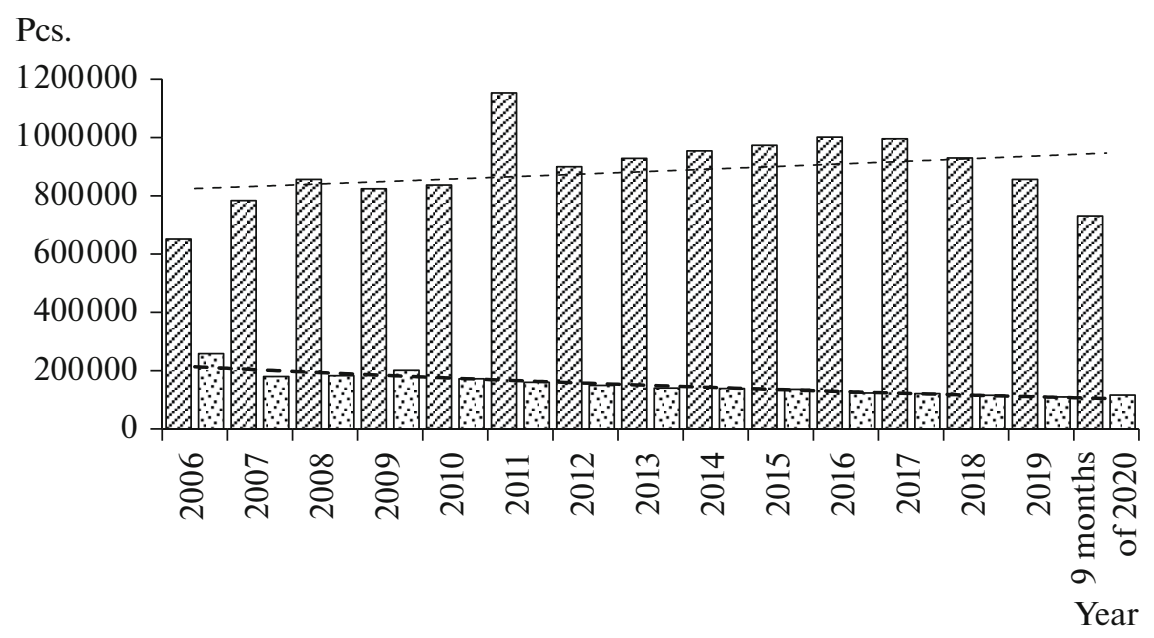

Fig. 1. Profitable (Q) and unprofitable ( -2$)$ organizations: --- exponential (profitable); --- exponential (unprofitable). Source: compiled by the authors based on statistical tax reporting data (Form 5-P).

tax, and so far the practice of calculating and paying it is only being formed. In the second case, it can be assumed that the increase in revenues is caused, first of all, by the traditional increase in tax rates. The volume of tax revenues for certain types of excisable goods increased even more significantly than for excise taxes as a whole. For example, receipts from excise taxes for ethyl alcohol and alcohol-containing products increased in 2020 by 2.5 times compared to 2019 [4]. In addition, according to Rosstat, during the period of self-isolation, the consumption of excisable goods, such as alcohol and tobacco products, increased quite significantly [5]. This circumstance, of course, also contributed to an increase in the inflow of excise receipts. There was also an increase in personal income tax (PIT). Compared to 2019, in 2020 the corresponding revenues increased by $7 \%$, which roughly corresponds to the increase in budget tax revenues from this tax for 2019 [3].

It should also be noted that the above situation developed by the results of 2020, while at the end of eight months of 2020 the picture was somewhat different. In particular, for the period of January-August 2020, the budget system of the Russian Federation received 9\% less taxes and fees, and the consolidated budget of the Russian Federation 12.2\% less, than on the same date in 2019. Decrease in tax revenues to consolidated budgets of the constituent entities of the Russian Federation in January-August 2020 compared to the same period in 2019 amounted to $6.3 \%$ [3].

In addition, it should be noted that there has been a significant change in the share of certain taxes in tax revenues. For example, the share of mineral extraction tax (MET) in the tax revenues of the consolidated budget of the Russian Federation in the period of January-August 2020 was $20 \%$, and for the same period of 2019, 27\% [3] (in earlier periods it was also at a level of $27 \%$ [6]). This circumstance is due to a decrease in the consumption of energy resources, primarily hydrocarbons, in the context of a pandemic.

Also, revenues from corporate income tax decreased, as of September 1, 2020, they decreased by $17 \%$ compared to the same period in 2019 [3]. A similar picture was observed during the entire period of self-isolation. Revenues from the tax on the extraction of minerals decreased as well. As of September 1, 2020, MET revenues were $37 \%$ less than as of September 1, 2019 [3]. A decrease in revenues was observed in relation to the majority of property taxes and taxes paid in connection with the application of special tax regimes.

However, at the end of 2020, there was a tendency towards some stabilization of the flow of tax revenues to the country's budget system, possibly due to some outlined improvements in the economy as a whole, as well as due to the termination of the coronavirus tax incentives.

Personal income taxation and social inequality. As noted earlier, the collection rate of personal income tax has remained nearly unchanged in recent years, including during the pandemic. Accordingly, it can be assumed that, in general, the size of the tax base-the taxable income of the population-remained approximately at the same level as in previous tax periods. The sources of income of the population are also of great importance. The main ones are the following: income from entrepreneurial and other production activities, income in the form of wages of employees, social benefits, income from property and other cash receipts.

The bulk of the population's income is traditionally formed at the expense of wages. The share of remuneration from employment in the total amount of cash income was, according to Rosstat, from 2013 to the present, approximately $50-60 \%$, the share of income from entrepreneurial and other production activities 


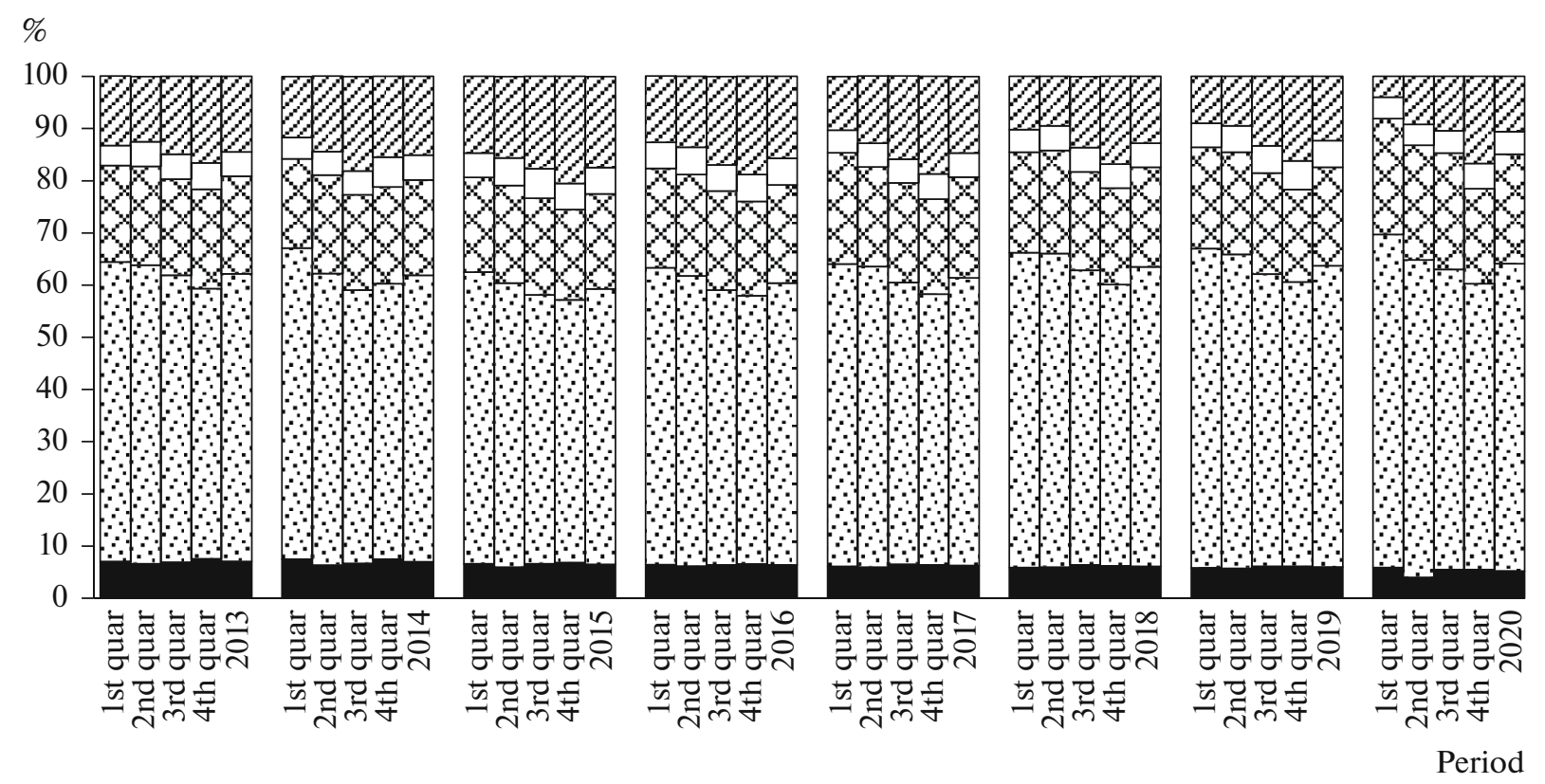

Fig. 2. Income structure of the population of the Russian Federation in 2013-2020:

$\square$ income from entrepreneurial and other production activities; 3 compensation of employees; $\square$ social payments; $\square$ property income; $Q$ other cash receipts. Source: compiled by the authors based on Rosstat data [5].

from 2013 to 2020 varied from 7.0 to $5.2 \%$. At the same time, on the whole, there was a general, rather stable trend towards a decrease in the share of income from entrepreneurial activity in the total monetary income of the population. In addition, a certain number of persons engaged in entrepreneurial activity do not submit the required reporting, or submit "zero" reporting. At the same time, the total number of entrepreneurs who submitted zero declarations and liquidated individual entrepreneurs and peasant farm enterprises ${ }^{2}$ exceeds the number of individual entrepreneurs and peasant farm enterprises created by about $9 \%$ in 2018, by $20 \%$ in 2017, and by $35 \%$ in 2016 [3]. Thus, the number of entrepreneurs who have ceased their activities consistently exceeds the number of newly created individual entrepreneurs. This circumstance, along with a decrease in the share of income from entrepreneurial activity in the total amount of income of individuals, may indicate a decrease in the entrepreneurial activity of the population of Russia. Data for later periods, including for the period of the pandemic, are currently not available, but it is fair to assume that the situation will look even more pessimistic.

It is almost impossible to unambiguously determine the trend of changes in the share of income from property and from other monetary incomes of the population. Fluctuations in these indicators were too multidirectional.

\footnotetext{
${ }^{2}$ Peasant farm enterprise is a voluntary association of citizens for production or economic activities in the field of agriculture.
}

The only indicator, the share of which in the income of the population was steadily growing, was social payments (Fig. 2).

Thus, another important problem has emerged, which has become significantly aggravated during the crisis period. It consists in the need for urgent development of measures to stimulate the entrepreneurial activity of the population. On the one hand, this will reduce budget expenditures for the payment of additional social benefits, on the other hand, it will lead to an increase in tax revenues.

At the same time, before the start of the pandemic, another, rather interesting trend, manifested itself in a decrease in the number of the working population. But at the same time, there was an increase in the total income of the population and an increase in the level of the average annual income per person. This, in particular, is reflected in the analytical materials of the Federal Tax Service of Russia. For example, according to the Federal Tax Service, in 2017 the number of the working population decreased by $3 \%$, while the growth of income of the population over the same period was $5.6 \%$. The average per capita annual income increased by $8.9 \%$ [3].

At the same time, the Federal Tax Service of Russia claims that on average in the country, the expenses of citizens are more than $30 \%$ higher than their income. Similar information is provided in its research by the rating agency NCR (National Credit Ratings). It contains, in particular, the following data. Agency experts say that about 13 million people are involved in the shadow sector of the domestic economy. [7, p. 161, 8, 
9]. The NCR reports in its research that, according to the statistical tax reports of the Federal Tax Service of Russia, the number of employed citizens is $22 \%$ less than the number of employed according to Rosstat. Individual income tax payers are 58.9 million people. In turn, Rosstat claims that there are approximately 72.3 million working citizens in Russia. [8,9]. The NCR cites the existence of shadow employment as the main reason for such discrepancies. Budget losses from nonreceipt of tax revenues from personal income tax are approximately three trillion rubles. At the same time, experts argue that in the case of legalization of these incomes, the basic tax rate on personal income tax could be reduced from 13 to $11 \%$, the volume of tax revenues from personal income tax in this case will not change [7, p. 163, 8, 9]. Another option for redistributing the tax burden could be associated with the introduction of a nontaxable minimum income for citizens and a truly progressive scale of taxation for personal income tax. However, at present, in both cases, the possibility of withdrawing the hidden incomes of the population from the unobserved sector is highly doubtful. The bulk of the population receiving illegal wages is involved in small business, primarily in the service sector, small-scale production, etc. In most cases, payment is made in cash. It should be noted that this sector of the economy is rather weakly controlled by the tax authorities, not only in Russia, but also in almost all countries of the world.

In addition, the need to redistribute the tax burden between different income groups may be evidenced by the fact that the gap between expenses and income (in the direction of exceeding the latter) increases with income growth (from the first to the tenth decile group) and to the greatest extent manifests itself precisely in the 10th decile group, and maximally, in the 100 th percentile $[10]^{3}$. This circumstance is due, inter alia, to the fact that the wealthiest citizens have many more opportunities to conceal their income and use tax preferences. In addition, the current tax legislation of the Russian Federation provides for the greatest opportunities for the application of tax incentives specifically for high-income groups of the population. In particular, the most significant tax benefits are provided for the acquisition of real estate, transactions

\footnotetext{
${ }^{3}$ In more detail the results of our study of the financial behavior of households by decile groups in Russia are presented in the article [10]. The calculations use data from the Rosstat Household Budget Sample Survey. Belonging to the decile group is determined by Rosstat in terms of the amount of available resources, which include not only cash income, but also the amount of funds attracted and savings spent and the cost of inkind income. Probably, for a more correct isolation of the really rich (10th group) and identification of the characteristics of this group, it is also necessary to consider the corresponding distributions by other indicators, such as average per capita money income. This method and the results of calculations are presented in the article of the authors, which will be published in the collection of Scientific Works of the Institute of Economic Forecasting of the Russian Academy of Sciences for 2021.
}

with financial assets, payment for expensive treatment, etc. With the growing gap between the richest and the poorest, this problem is only exacerbated.

The decline in real household incomes affected, first of all, the groups of the population with the lowest level of income and hardly affected the high-income groups. This circumstance is an additional argument in favor of the thesis about the urgent need to reform the existing system of income redistribution in the Russian economy.

It should be noted that, in contrast to all other decile groups, in the 10th group the sum of average per capita cash expenditures exceeds the sum of average per capita cash incomes. Due to the outstripping growth of cash expenditures, the gap widens in the precrisis years (2007-2008 and 2013-2014), and in the crisis years of 2009 and 2015 almost disappears due to their sharp decline. The tenth decile group (the richest) is distinguished by the excess amount of cash expenditures over cash income (Fig. 3).

Almost a third (about 30\%) of households in this group spent additional funds in excess of their monetary incomes. At the same time, in the previous crisis periods, this share decreased to about $23 \%$, and then the value of the indicator returned to the previous level. A similar situation prevailed before the current round of the crisis (Fig. 4) [10, p.73].

The tax burden is unevenly distributed between different income groups. In contrast to many developed countries, in Russia, the poorest people have the greatest burden [11], and the tax burden decreases from the first to the tenth group. According to the information of the Federal Tax Service of Russia, the tax burden in relation to individuals (for personal income tax and property taxes), on average in the Russian Federation, in 2017 was 13.34\%. In 2016 and 2015, it was at the same level, 13.32 and $13.35 \%$, respectively [3].

If we consider a broader set of mandatory payments, then it would be more correct to talk about the fiscal burden. This indicator is calculated taking into account not only taxes, but also other obligatory payments (see details in [1]). Accordingly, it can be assumed that the indicator of the total fiscal burden is much higher.

We determined the fiscal burden using the following formula:

$$
\mathrm{FB}=\mathrm{TFMP} /(\mathrm{GIH}-\mathrm{CE}),
$$

where FB is the fiscal burden; TFCP is the taxes, fees, other mandatory payments paid by households; GIH is the gross income of households; $\mathrm{CE}$ is the consumer expenditures of households.

Indeed, the average level of the fiscal burden of individuals in Russia in 2018, according to our calculations, was about $26 \%$, and its maximum value (31\%) was reached in 2007. In general, from 1997 to the present, the total fiscal burden in relation to taxpayers individuals increased by about $47 \%$ [7, p. 167]. 


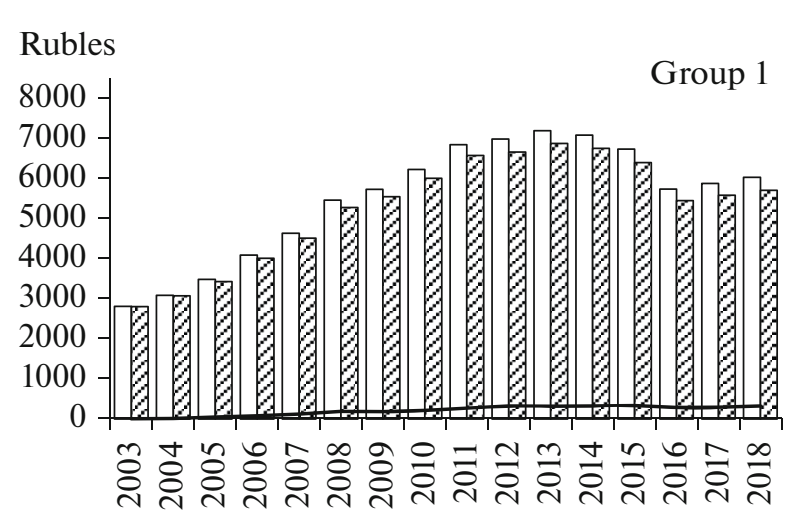

Rubles
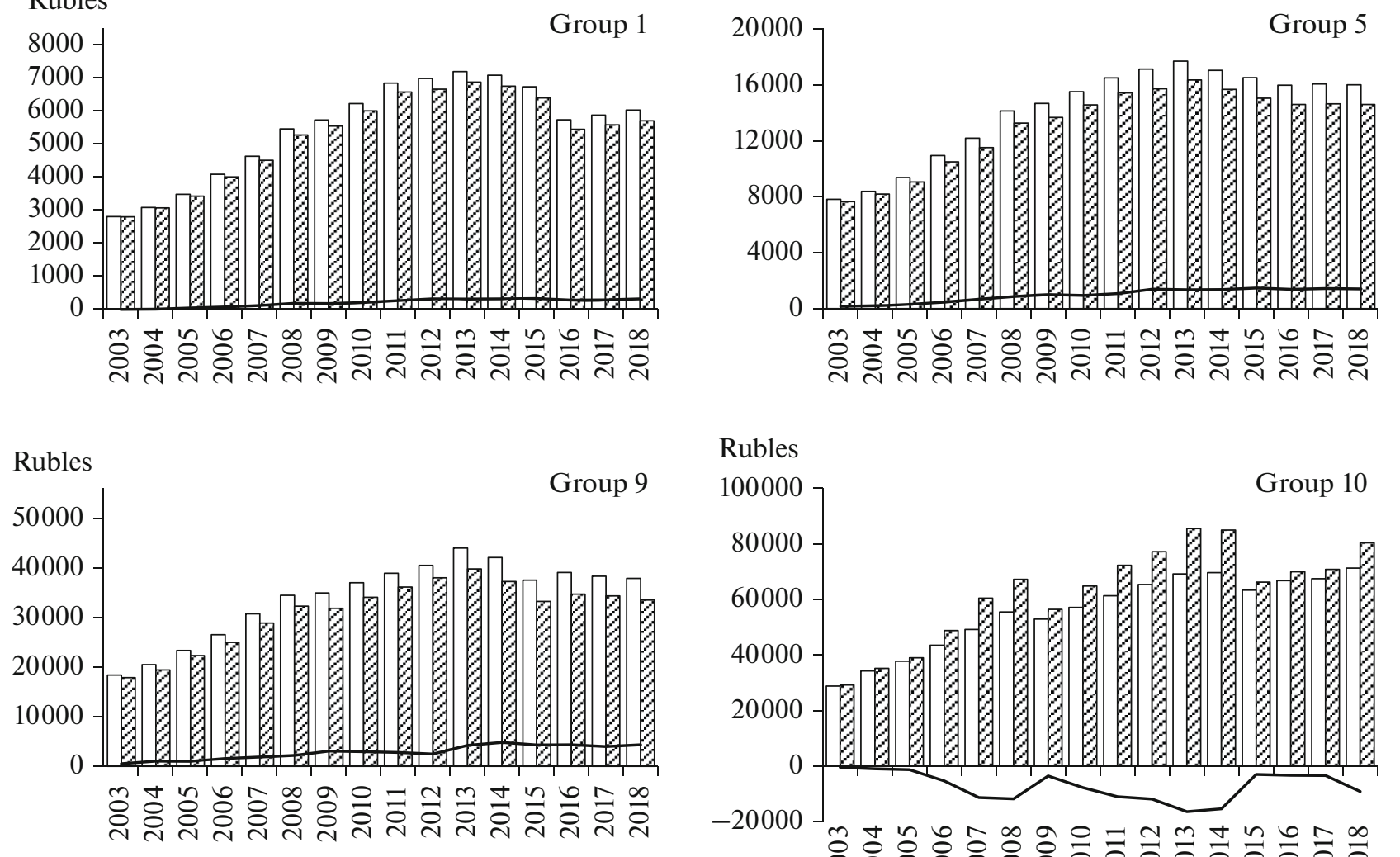

\section{Rubles}

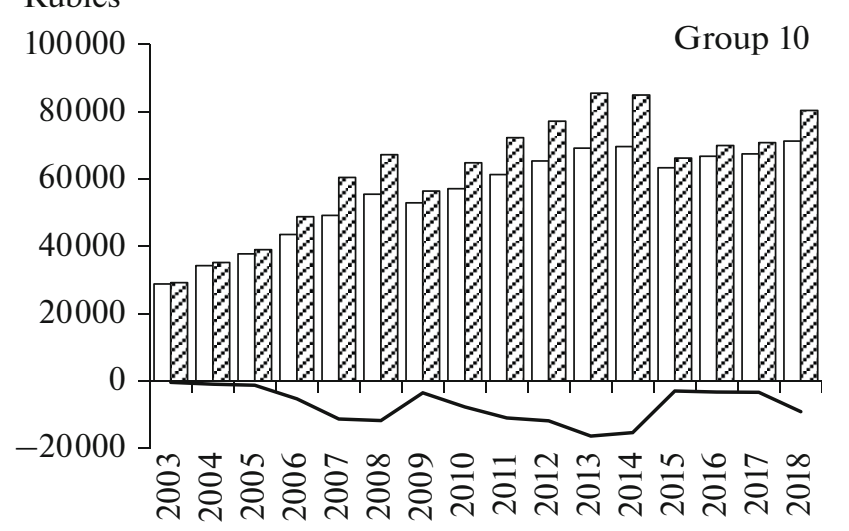

Fig. 3. Average per capita cash income $(\square)$ and expenses ( $Q$ ), and growth of financial assets ( $\longrightarrow$ ) by decile groups per month in 2003-2018 in prices of 2018. Source: compiled by the authors based on Rosstat data [5].

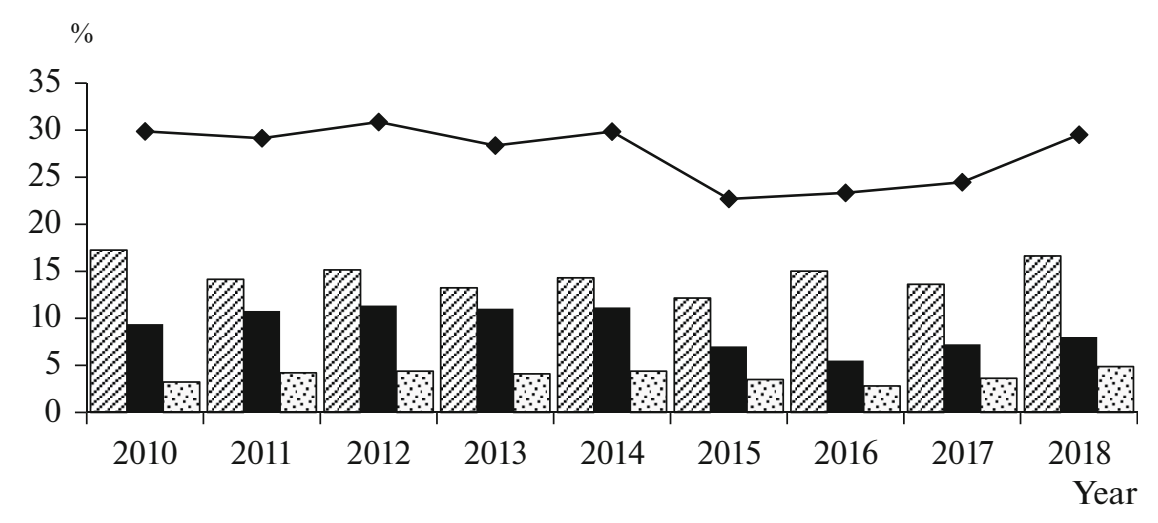

Fig. 4. Share of households using additional sources of cash other than cash income to cover cash expenses, decile 10, 2018:

$\square$ spent savings; took out loans; $\because$ spent savings and took out loans; $-\bullet-$ used additional sources of cash in total.

Source: authors' calculations based on Rosstat data [5, 10].

The lowest fiscal burden was noted in the 10th decile group [11, p. 765]. The fiscal burden in this group from 2003 to 2018 fluctuated from 16 to $27 \%$, with its lowest values reached in 2015 (13.8\%). In the first decile group (the poorest population) in 2018, the load was equal to $30.8 \%$, and from 2003 to 2018 its maximum value (40.7\%) was reached in 2013 (Fig. 5). This value of the fiscal burden as a whole was the maximum for all decile groups in the indicated period [5, 12, p. 766].

In most developed countries, by contrast, the richest strata of the population bear the greatest burden, 


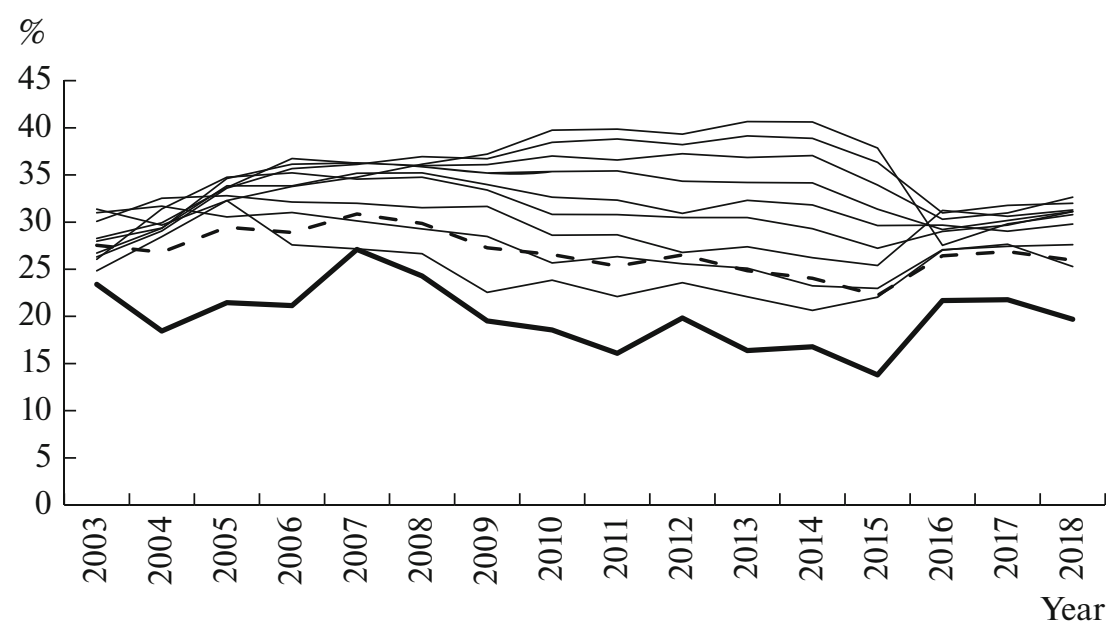

Fig. 5. Fiscal burden by decile groups: --- all households; - decile groups $1-9$; — 10th decile group. Source: authors' calculations based on Rosstat data [5, 8, 9].

while the poorest pay less tax. Thus, one of the ways to narrow the income gap between the richest and the poorest citizens could be to equalize the tax burden by additional taxation of the group with the highest income. At the same time, the 100th percentile can be distinguished as the target group ${ }^{4}$, since the real gap in most indicators is present precisely here. The solution to this problem is possible, in particular, by introducing in the Russian Federation a truly progressive scale of taxation on personal income. Possible options for such a reform with an assessment of their potential effectiveness have been actively discussed in recent years; currently, some steps in this direction have already been taken.

However, it should be noted that the complexity of the task is aggravated by the fact that there is no uniformity of opinions regarding methods for calculating the tax burden among researchers. For example, there is uncertainty in relation to the attribution of payments to tax payments proper, in relation to income indicators used in the calculations, etc. $[13, \text { p. } 54]^{5}$.

Most significant changes in the Russian Tax System. The upward trend in inequality between different social groups is observed in almost all countries. Recovery from such a crisis, according to researchers from the charity institution Oxfam, will take at least ten years. The consequences of the pandemic could be overcome faster, but this is only possible if a "fairer economy" is built [14].

\footnotetext{
${ }^{4}$ As noted above, the belonging of households to one or another decile and percentile in Rosstat statistics is determined by the value of the average per capita disposable resources.

${ }^{5}$ As noted, the authors calculated the fiscal burden for each decile group as the ratio of taxes and other mandatory payments paid by households to the amount of income remaining at their disposal after deducting the expenses incurred.
}

Russia has become one of the countries that have been significantly affected during the pandemic period. Especially significant coronavirus restrictions were manifested in the 2nd quarter of 2020. During this period, the real incomes of Russian citizens experienced record-breaking drops, and unemployment increased to its maximum value over the past eight years [15]. Thirteen point five percent of the population, or 19.9 million people, were below the poverty line [14]. At the same time, every fifth family in need was not provided with the necessary state financial support. One of the reasons for this situation could be the insufficient targeting of the assistance provided. However, the richest Russian billionaires in 2020 became richer by about 33 billion dollars [16].

At the same time, world practice shows that a decrease in the differentiation of incomes and the level of poverty of the population is, to a certain extent, possible. It is achievable, in particular, through the redistribution of income by the state through social transfers, on the one hand, and a progressive scale of taxation of personal income, on the other. The effectiveness of these redistributive measures in many countries is quite high. In countries such as Germany, Denmark, Sweden, the share of the population with incomes below the poverty line after receiving social benefits is reduced by $2-3$ times, in Austria, Belgium, Great Britain, France by 1.5-2 times [17, p. 9].

The Russian system of taxation of personal income is fundamentally different from the model operating in most developed countries. In Russia, until recently, a proportional scale of personal income tax was applied. In fact, it continues to be applied at the present time. Tax deductions for low-income groups of the population are insignificant, and standard tax deductions were abolished altogether in 2012. The existing tax breaks are intended primarily for use by high-income groups of the population. Thus, the use of property tax 
deductions is possible when purchasing and building housing, paying for medical services, including expensive ones, and educational services. In addition, domestic tax legislation provides for the application of tax deductions when performing various transactions with financial instruments. These operations are also the prerogative of the richest. As a result, the tax burden of low-income groups of the population is lower than that of the wealthiest citizens [17, p. 9].

At present, according to the authorities, in the Russian Federation there is already a redistribution of the tax burden in the direction of taxation of the income of the wealthiest citizens. In particular, this is realized through an increase in the tax rate on personal income from 13 to $15 \%$ with respect to income exceeding five million rubles. In addition, in Russia, increasing coefficients for transport tax are already applied in relation to powerful expensive cars. An increase in the personal income tax rate, according to experts, will entail an increase in tax revenues from this tax to the budgetary system of the state by 60 billion rubles, which are supposed to be targeted for the treatment of seriously ill children [18]. At the same time, starting from 2021, new tax advantages have appeared for wealthy citizenstax residents of the Russian Federation. These preferences relate to the taxation of profits of controlled foreign companies (CFCs), in relation to which these individuals are controlling persons. The new rules provide an opportunity for CFC owners to pay tax at a fixed rate, which is five million rubles. This removes the obligation to disclose tax information. This innovation has become a kind of "indulgence for the rich for little money" [19]. These innovations limit the ability of regulatory authorities to analyze information about foreign assets of domestic business. Given the fact that the introduction of the institution of controlled foreign companies into the tax legislation was primarily aimed at the possibility of obtaining and using the most transparent and complete information for tax purposes, the above changes can be assessed as a "step backward" in tax administration. The new procedure for taxing the profits of CFCs controlled by Russian individuals is most beneficial for those citizens whose annual income exceeds 40 million rubles and who holds at least 10 million dollars in controlled foreign companies with an expected return of 5\%. A number of experts argue that such controlled foreign companies are in the majority [19].

At the same time, as the practice of tax administration shows, the incomes of the wealthiest citizens do not fall into this group and are barely subject to any control. Accordingly, the tax liabilities of the "superrich" citizens, as before, are not controlled in practice, and the incomes of the "relatively super-rich" are controlled to a lesser extent than before the tax innovations.

Conclusions. It is obvious that at present there is an urgent need to implement a number of measures, including tax ones, aimed at reducing inequality. Among such events, the following can be distinguished.

First of all, it is necessary to transform the domestic tax system in such a way that this would lead to a redistribution of the tax burden between different groups of the population on the basis of the principle of fairness of taxation. To solve this problem, as a matter of priority, it is necessary to introduce a truly fullfledged progressive scale of taxation, rather than taxation with the use of an increased tax rate on individual incomes.

It is also necessary to further develop tax administration in order to identify shadow income, especially of representatives of the wealthiest groups of the population. In addition to the fact that the representatives of the top decile have the highest incomes, they also have the opportunity to use the most sophisticated tools of aggressive tax planning. In addition, it is these groups of the population that most actively use various financial instruments to generate additional income and, accordingly, it is they who can apply tax benefits associated with the use of such instruments.

Along with changes in the taxation system, special attention should be paid to the implementation of measures of state support for socially unprotected families, especially families with children. In particular, according to estimates of individual experts, an increase in the income of $30 \%$ of the poorest Russian households with children due to the increase in the rate of child benefits may reach about $30 \%$ [10, p. 77].

As world practice shows, such a combination of tax and socially oriented measures leads to the greatest effect - the fastest elimination of the consequences of the crisis and the fastest recovery of economic growth.

\section{FUNDING}

The article was prepared with the financial support of the Russian Foundation for Basic Research (project No. 19-010-00878 "Managing the dynamics of demand for money using the interest rate-empirical research").

\section{REFERENCES}

1. Main Directions of the Budget, Tax and Customs Tariff Policy for 2021 and for the Planning Period of 2022 and 2023 (Approved by the Ministry of Finance of Russia) (Moscow, 2020) [in Russian].

2. Super-rich call for higher taxes on wealthy to pay for Covid-19 recovery. https://www.theguardian.com/news/2020/jul/13/super-rich-call-for-higher-taxes-on-wealthy-to-pay-for-covid-19-recovery.

3. Federal Tax Service Official site. https://www.nalog.ru.

4. Russian Federal Treasury Official site. https://roskazna.gov.ru.

5. Russian Federal State Statistics Service Official site. https:// rosstat.gov.ru. 
6. L. B. Mokhnatkina, "Assessment of regional inequality in the formation of federal budget revenues based on the Pareto criterion,” Ekon. Reg. 16 (4), 1377-1392 (2020). https://doi.org/10.17059/ekon.reg.2020-4-25

7. E. V. Ordynskaya and M. V. Cherkovets, "Influence of financial policy on the distribution of incomes of the population" in Proceedings of the Second Conference of the Institute of Economic Forecasting (Russian Academy of Sciences) and the Institute of Economic and Industrial Production Organizing (Siberian Branch, Russian Academy of Sciences) on Intersectoral and Regional Analysis and Forecasting "Economic Policy of Russia in CrossSectoral and Spatial Dimensions" (Novosibirsk, 2020), vol. 2, pp. $153-174$.

8. Research: the informal sector employs 13 million Russians, RIA Novosti, 2019, Dec. 10. https://news.mail.ru/economics/39804839.

9. Invisible citizens: 3 trillion rubles out of sight of the Federal Tax Service due to shadow employment. https://ratings.ru/analytics/macroeconomics/employment-IncomeTax-101219/.

10. M. V. Cherkovets and E. V. Ordynskaya, "Features of the financial behavior of households with different income levels and the possibility of reducing inequality using fiscal policy measures" Nauchn. Tr. Inst. Narodokhoz. Prognozirovnaiya, Ross. Akad. Nauk, No. 2020, 59-80 (2020).

11. L. N. Lykova, "Possibility of returning to progressive income taxation of individuals in Russia," Vestn. Inst. Ekon., Ross. Akad. Nauk, No. 6, 32-51 (2013).

12. E. V. Ordynskaya, "Certain tax aspects of ensuring economic security" in Russia in the 21st Century: Global
Challenges and Development Prospects. Materials of the Fourth International Forum (Moscow, 2015), pp. 763770.

13. I. Dezhina, T. Nafikova, T. Gareev, and A. Ponomarev, "Tax incentives for the competitiveness of telecommunications companies," Forsait 14 (2), 5161 (2020).

14. Social inequality of record proportions was predicted for the world. https://news.mail.ru/economics $/ 45000169 /$ ?frommail $=1$.

15. HSE economists report reduction of middle class in Russia due to pandemic. https://news.mail.ru/society/43516400/.

16. L. Hirsch, Patriotic Millionaires' letter to Davos calls for 'higher and fairer' taxes on the global elite, 2020 https://www.cnbc.com/2020/01/22/davos-2020-patriotic-millionaires-letter-calls-for-higher-taxes-onglobal-elite.html.

17. A. V. Suvorov, O. N. Boldov, V. N. Ivanov, G.M. Sukhorukova, and A.I. Budanova, "Directions of social policy ensuring the restoration of economic growth in Russia," Probl. Prognozirovaniya, No. 4, 3-15 (2020).

18. Peskov commented on the petition of millionaires calling for an increase in taxes on wealth. https://tass.ru/ekonomika/8956345.

19. Half of the Russian rich used "Putin's gift for the Forbes list". https://news.mail.ru/economics/45404913/?frommail $=1 \&$ exp_id $=868$.

Translated by S. Avodkova 